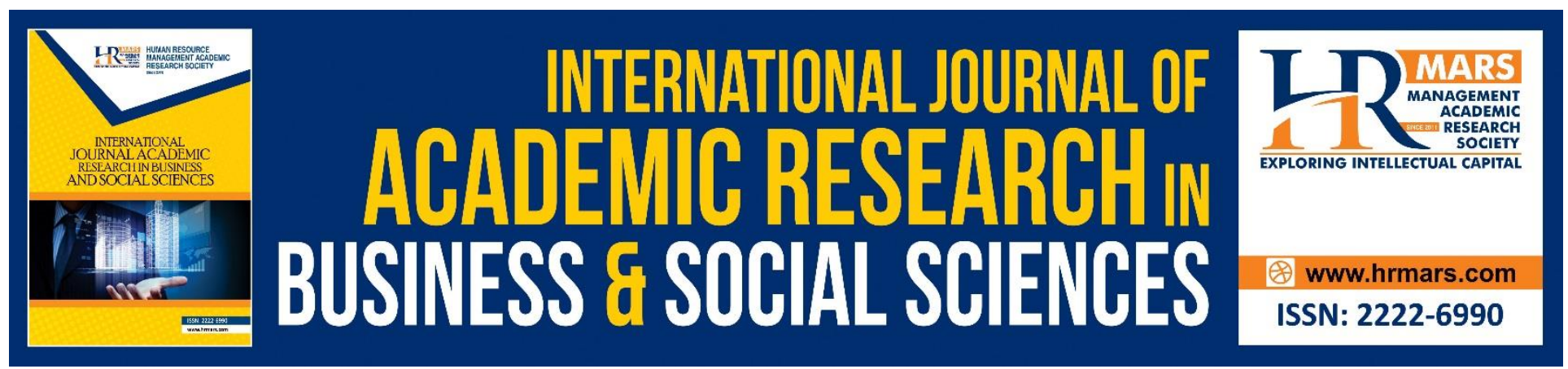

\title{
The Teaching of Malay Essay Writing based on an Authentic Approach
}

\section{Zulkifli Osman, Anida Sarudin, Dahlia Janan, and Ani Omar}

To Link this Article: http://dx.doi.org/10.6007/IJARBSS/v9-i1/5485

DOI: $10.6007 /$ IJARBSS/v9-i1/5485

Received: 20 Dec 2018, Revised: 15 Jan 2019, Accepted: 27 Jan 2019

Published Online: 06 Feb 2019

In-Text Citation: (Osman, Sarudin, Janan, \& Omar, 2019)

To Cite this Article: Osman, Z., Sarudin, A., Janan, D., \& Omar, A. (2019). The Teaching of Malay Essay Writing based on an Authentic Approach. International Journal of Academic Research in Business and Social Sciences, 9(1), 846-859.

Copyright: (C) 2019 The Author(s)

Published by Human Resource Management Academic Research Society (www.hrmars.com)

This article is published under the Creative Commons Attribution (CC BY 4.0) license. Anyone may reproduce, distribute, translate and create derivative works of this article (for both commercial and non-commercial purposes), subject to full attribution to the original publication and authors. The full terms of this license may be seen at: $\underline{\text { http://creativecommons.org/licences/by/4.0/legalcode }}$

Vol. 9, No. 1, 2019, Pg. 846 - 859

http://hrmars.com/index.php/pages/detail/IJARBSS

JOURNAL HOMEPAGE

Full Terms \& Conditions of access and use can be found at http://hrmars.com/index.php/pages/detail/publication-ethics 


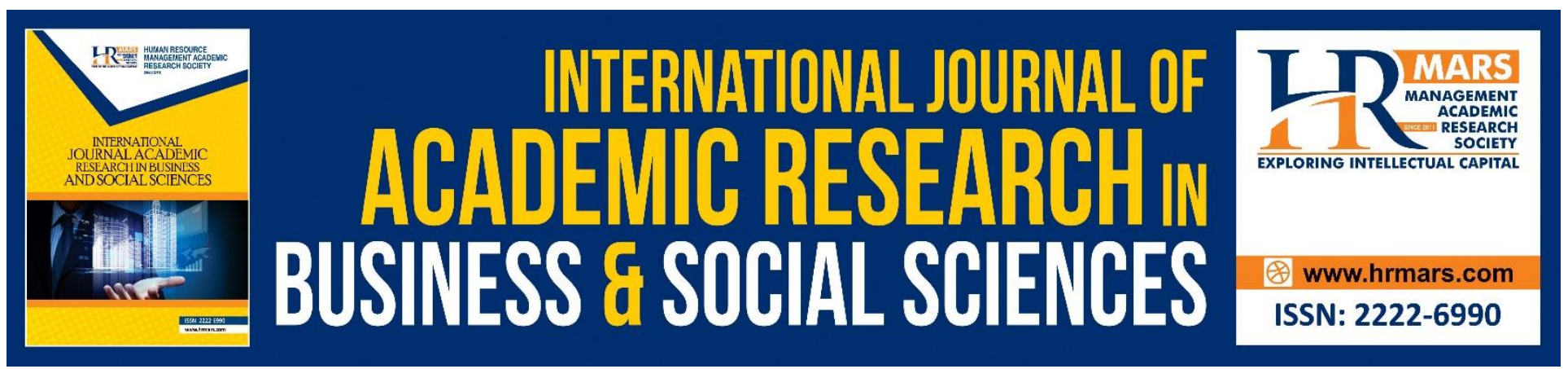

\title{
The Teaching of Malay Essay Writing based on an Authentic Approach
}

\author{
Zulkifli Osman, Anida Sarudin, Dahlia Janan, and Ani Omar \\ Faculty of Languages and Communication, Sultan Idris Education University, Malaysia
}

\begin{abstract}
In this paper, the authors discuss the principles and models of authentic learning, which have been proposed by several leading experts in the field of authentic learning. Among the principles, authentic learning materials, authentic assessment, and teaching and learning activities based on the real world are the core principles shared by most models. In particular, the authors propose an authentic learning model that will be used for the essay teaching process in the classroom consisting of six important principles, namely actual (hands-on) learning materials, easily accessible learning sources that are realistic and tangible, emphasis on community input, outdoor activities, and freedom for students to express their views and interpretations, and authentic assignments. Using these principles, the authors propose a practical implementation of the teaching and learning activities based on this approach for the teaching of essay writing. With such proposed activities, teachers and instructors will be able to plan and carry out their essay writing classes more effectively through which their students will learn more meaningfully.

Keywords: Authentic Assessment, Authentic Learning, Essay Writing, Learning Context, Teaching Approach.
\end{abstract}

\section{Introduction}

The authentic teaching of Malay language is able to create an interesting learning environment that provides a learning opportunity for students to experience a meaningful learning process. In particular, through the principle of 'learning by doing' and contextualized learning, the student learning process will become more meaningful that helps improves and retains their understanding and knowledge of a particular concept over a longer duration. In this regard, the Malay Language Primary School Standard Curriculum (Kurikulum Standard Sekolah Rendah Bahasa Malaysia) (2012) and the Malaysian Educational Development Plan 2013-2025 (Pelan Pembangunan Pendidikan Malaysia 2013-2025) highlight the emphasis on learning based on authentic learning materials and activities. 
Despite such an emphasis, the current learning environment of the Malay language learning in the classroom is heavily oriented toward examination (Zulkifley Hamid, 2000; Radiah Yusoff et al.,2010; Zulkifli Osman, 2013a). For example, several studies have shown that most teachers rely on the textbook as the main learning material for such learning (Zulkifli Osman, 2013a; Zulkifli Osman, 2013b; Mahzan Arshad, 2003). Engaged in such a context, naturally, students will be deprived of diverse learning materials, in particular materials with authentic characteristics. Furthermore, the current learning environment in the classroom seems divorced from reality. More revealingly, studies by Zulkifli Osman (2013c) and Masoud, Fatemeh, dan Seyyed (2014) provide a number of interesting findings, in which they found that students preferred to use authentic learning materials in Malay language learning. In fact, the use of such learning materials had made the students become more discernable about and appreciate the Malay culture of the society. In addition to these findings, authentic learning has been proven to be effective in improving students' achievements and creativity (Hazrati, Rosseni, Aidah, Helmi dan Analisa, 2013).

As amply demonstrated by the above revelations, authentic learning should be used by teaching teachers and instructors to help them realize meaningful learning condition, in which their students could learn more efficaciously. In addition, previous studies (Richards, 2001; Mahzan Arshad, 2003; Zulkifli Osman, 2013a; Zulkifli Osman, 2013b; Brown, 2001; Mary Tan Mun Yee, 2012) have shown that such learning using authentic learning activities and materials are able to improve students' motivation and achievements. In view of the lack of research on the Malay language learning based on such an approach, the researchers will undertake the effort to develop a Malay language teaching module that was based on the principles of authentic learning. More specifically, the development of the learning materials and teaching and learning activities, which took into account such principles, would help a group of students to experience a meaningful, interesting learning environment in which they could improve their composition or writing skill of the Malay language.

\section{Authentic Learning Principles}

According to Zemelman, Daniels, and Hyde (2005), authentic learning is not a method, but a condition that engenders a learning condition based on an approach, activities, and learning tools that are authentic in nature. In this respect, Zemelman and his colleagues argue that the main aim of such learning is to make learning condition more in touch with reality, which is in line with their 'make it real' concept. To help realize such a concept, two approaches could be implemented to make a learning environment become realistic, namely by bringing in the 'world' into the classroom and by taking out the students to the outside 'world'. Such a concept reinforces that the teaching and learning process could not be separated from the reality of the outside world. Of late, such a teaching and learning process that helps students learn meaningfully has become more prominent in the educational realm. The shift from conventional learning to authentic learning has taken place in earnest as latest research has shown that student-centered, realistic learning condition would have a profound impact on the quality of student learning (Herrington and Herrington, 2007). To help create authentic learning condition, Zemelman and his colleagues (2005) developed a number of guidelines as follows:

a) Materials to be used need to be artifacts that are tangible such that they can be held or touched. 
b) Learning characterized by 'learn-by-doing' needs to be prioritized over learning characterized by 'learn-by-sitting' (or static and passive).

c) Teaching and learning activities in the classroom that need to be carried out have to be aligned with the current issues.

d) Teaching and learning activities need to blend with students' multiple intelligences and learning styles.

e) The use of actual materials, such as newspapers, should be given more emphasis over the textbooks and those provided by publishers.

f) Available materials and those that can be easily accessed (which not textbooks) have to be used as much as possible.

g) Students' assignments should involve the support, assistance, and assessment of family and community whenever possible.

h) Subject matter experts have to be involved to help students to gain a direct access to information.

i) External activities need to be encouraged to help students to gain a direct access to information.

j) Students need to be engaged in local community programs.

k) Inquiry-based techniques, such as interviews, observations, and field work, have to be adopted in the teaching and learning process.

I) Students' assignments should be shared with the general public.

In addition, Muijs and Renolds (2011: 79) contend that language learning that is meaningful can take place when students will be able to construct their own knowledge through a learning process that is active, involving the search of meanings, social constructs, and sufficient knowledge among the teachers, which is delivered contextually with the use of effective materials in a learning environment that is both realistic and authentic. On the other hand, Lombardi (2007) deconstructs the concept of authentic as learning that focuses on the real world, involving real problems, with the use of roleplay technique, problem-based activities, case studies, and student involvement in the community. In essence, authentic learning focuses on meaningful learning that reflects or represents aspects of the real world.

In implementing such authentic learning, Lombardi (2007) asserts that learning activities have to be relevant to the actual practices of the real world. As such, he emphasizes that students' assignments need to be developed that can help foster meaningful interpretations through inquiry-based activities, such as field study, and to provide students the opportunity to construct their perspectives from diverse sources. In addition, Lombardi (2007) argues that such learning will be able to foster collaboration among students and enable them to make choices and reflect on the learning process. From the assessment standpoint, the same researcher stresses that formative assessments need to be given a strong emphasis based on problems that are relevant to the real world. In short, authentic learning helps train students to solve real-world problems through learning activities.

From the methodological perspective, Donavan, Bransford, and Pellegrino (1999) and Newmann, Secada, and Wehlage (1995) argue that authentic learning and traditional learning differ significantly. To help highlight such a difference, they outlined several characteristics of authentic learning, one of which is that such learning focuses on authentic tasks that entail students to engage in explorative, inquisitive learning. Furthermore, such learning is closely related to the real world, 
INTERNATIONAL JOURNAL OF ACADEMIC RESEARCH IN BUSINESS AND SOCIAL SCIENCES

Vol. 9, No. 1, Jan, 2019, E-ISSN: 2222-6990 @ 2019 HRMARS

extending beyond the confines of the classroom. In addition, authentic learning will use challenging assignments to compel students to engage in higher order thinking, such as analyzing, synthesizing designing, manipulating, and making an assessment. Students are also encouraged to produce products that can be shared with the local community, in particular through social activities, such a social discourse. To help create an authentic learning environment, Herrington and Herrington (2007) proposed nine approaches as follows:

a) Provide authentic contexts to ensure knowledge can be applied in the actual contexts.

b) Create authentic learning activities that are relevant to the real world and complex assignments that need to be completed based on a prescribed duration.

c) Exposure students to the problem-solving process or to assignments that are realistic with the actual contexts.

d) Encourage students to explore multiple perspectives and diverse roles.

e) Collaborate with one another to help develop knowledge.

f) Reflect on the problems and their solutions.

g) Articulate discussions among students.

h) Provide scaffolding for students during the learning process.

i) Carry out the authentic assessment.

As highlighted above, it is evidently clear that there are several principles or models that serve as the foundation for authentic learning. Admittedly, some of the principles share a common notion, positing that authentic learning focuses on a learning process that is based on reality. As such, such learning emphasizes activities, materials, and assessments that represent the real world that is both realistic and authentic. In addition, authentic learning encourages students to get involved with the local community or its environment in each learning activity whenever possible. Another important aspect of such learning is that it also stresses active learning involving an inquiry-based process. Figure 1 highlights the core principles of authentic learning for language learning. 


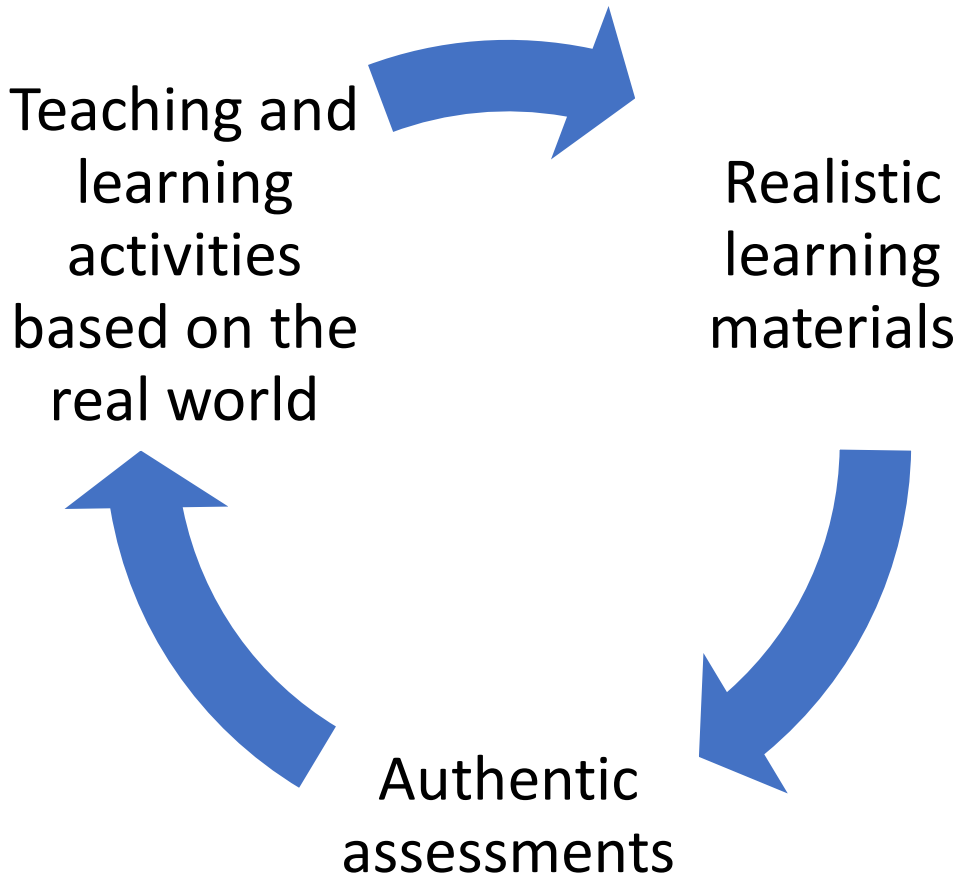

Figure 1. The core principles of authentic learning for language learning

\section{Authentic Learning Model}

To help implement authentic learning, a number of models have been proposed by several leading scholars, including the model developed by Zemelman and his colleagues (2005), Lombardi (2007), Donavan, Bransford, and Pellegrino (1999), and Herrington and Herrington (2007), the synthesis of which will show they consist of several important principles, such as authentic learning materials, authentic learning sources, the role of community, authentic activities, freedom in making interpretations, and the type of assignments. From the aspect of learning materials, it is clear that materials to be used for learning based on the above models are real, hands-on artifacts that are relevant with current issues and appropriate with students' diverse learning styles. From the aspect of sources, immediate learning sources, such as those related to students' family or local leading personalities, are the natural choice based on such learning models. Such models also advocate strongly the use of interviews, observations, and fieldwork through which students will be able to gain important information.

Likewise, communal aspect is also an important focus of such learning models, which emphasizes that learning activities must involve the local people and encourages that students provide suggestions, make plans, and conduct assessments of projects or issues prevailing in the 
community. In addition, such learning models stress the importance of providing sufficient opportunities for students to display their works or assignments to the public. In actuality, these models also encourage students to develop products that can be shared with the public and to directly engage with specific segments of the local community (such as firemen), the engagement of which will help the students to gain real, relevant information directly that is deemed vital for their specific assignments. For example, in composing an essay with regard to the experience of extinguishing fires, firemen will be the most appropriate individuals to be invited to the classroom to share their real experiences with the students such that the latter will be able to acquire the relevant facts and precise information, with which interesting and appealing narrative can be developed.

From the aspect of activities, such learning models stipulate that both students and teachers to conduct outdoor activities and visits, such that the former will not be confined in their classroom. Specifically, such visits will provide an opportunity for the students to see the outside world that can help them to carry out their assignments more meaningfully. In addition, the learning models emphasize inquiry-based activities to help improve students' knowledge and skills and advocates the use of relevant scaffolding for learning activities. Likewise, such learning models also stress the freedom that can help students in carrying out their assignments and learning activities more efficaciously. With such freedom, students will have more opportunities to use their interpretations in solving their tasks, as opposed to learning based on the conventional approach. In addition, students will be encouraged to fully use their capability with the support of their parent, family, and the public. From the aspect of assignments, such learning models place a strong emphasis on the use of authentic, inquiry-based assignments that entails students to engage in higher order thinking skill (HOTS), complex tasks that require students to solve within a given duration, and authentic assessments. Table 1 summarizes the principles of the authentic learning models discussed above. 
INTERNATIONAL JOURNAL OF ACADEMIC RESEARCH IN BUSINESS AND SOCIAL SCIENCES Vol. 9, No. 1, Jan, 2019, E-ISSN: 2222-6990 @ 2019 HRMARS

Table 1. The Principles of the Authentic Learning Models

\begin{tabular}{|c|c|c|c|}
\hline No. & Item & Description & $\begin{array}{l}\text { Example of best } \\
\text { technique and } \\
\text { approach. }\end{array}$ \\
\hline 1 & $\begin{array}{l}\text { Learning } \\
\text { material }\end{array}$ & $\begin{array}{l}\text { Actual, hands-on materials that are related to } \\
\text { the current issues and that are suitable with } \\
\text { students' learning styles. }\end{array}$ & \\
\hline 2 & $\begin{array}{l}\text { Learning } \\
\text { source }\end{array}$ & $\begin{array}{l}\text { Readily available sources, such as students' } \\
\text { families or local influential personalities. } \\
\text { Method of collecting information includes } \\
\text { interviewing members of the society, making } \\
\text { observations, and conducting fieldworks. }\end{array}$ & $\begin{array}{l}\text { 1. Talk by an } \\
\text { influential } \\
\text { personality. } \\
\text { 2. Interview. }\end{array}$ \\
\hline 3 & $\begin{array}{l}\text { Role of the } \\
\text { community }\end{array}$ & $\begin{array}{l}\text { The local community provides the required } \\
\text { information as input for the students. }\end{array}$ & $\begin{array}{l}\text { 1. Discourse by a } \\
\text { leading figure. } \\
\text { 2. Problems faced } \\
\text { by the local } \\
\text { community. }\end{array}$ \\
\hline 4 & Activity & $\begin{array}{l}\text { Encouraging outdoor activities and visits to } \\
\text { the outside world such that students will not } \\
\text { be confined to their classroom. }\end{array}$ & 1. Academic visit. \\
\hline 5 & $\begin{array}{l}\text { Interpretation } \\
\text { approach. }\end{array}$ & $\begin{array}{l}\text { Giving students the freedom to help make and } \\
\text { apply their own interpretations. }\end{array}$ & - \\
\hline 6 & $\begin{array}{l}\text { Type of } \\
\text { assignments }\end{array}$ & $\begin{array}{l}\text { Emphasizing the use of authentic, inquiry- } \\
\text { based assignments that entails students to } \\
\text { use higher order thinking skills (HOTS), } \\
\text { complex assignments that have to be } \\
\text { completed within a prescribed duration, and } \\
\text { authentic assessments. }\end{array}$ & - \\
\hline
\end{tabular}

\section{The Application of Authentic Elements in Writing Essay}

In the proposed study, nine elements of Herrington and Herrington's (2007) authentic learning approach will be used as the guidelines in creating an authentic learning environment, namely authentic context, authentic assignment, expert achievement, multiple perspectives and differential views, collaboration, reflection, articulation, training and scaffolding, and authentic assessment. Table 2 summarizes these elements that will be embedded in the teaching of Malay language composition. 
INTERNATIONAL JOURNAL OF ACADEMIC RESEARCH IN BUSINESS AND SOCIAL SCIENCES Vol. 9, No. 1, Jan, 2019, E-ISSN: 2222-6990 @ 2019 HRMARS

Table 2. The nine elements and the proposed authentic learning activities in the teaching and learning of Malay language composition

\begin{tabular}{|c|c|c|c|c|}
\hline No. & Element & Description & Issue & $\begin{array}{c}\text { Language } \\
\text { skill/Learning } \\
\text { material }\end{array}$ \\
\hline 1 & $\begin{array}{l}\text { Authentic } \\
\text { context. }\end{array}$ & $\begin{array}{l}\text { A physical or visual } \\
\text { environment that } \\
\text { reflects the knowledge } \\
\text { to be used in the actual } \\
\text { situation. }\end{array}$ & $\begin{array}{ll}\text { - } & \text { Complex scenario. } \\
\text { - } & \text { Real-world problem } \\
\text { and students' actual } \\
\text { environment. }\end{array}$ & $\begin{array}{l}\text { Reading online news } \\
\text { or any similar } \\
\text { materials to create an } \\
\text { authentic learning } \\
\text { context. }\end{array}$ \\
\hline 2 & $\begin{array}{l}\text { Authentic } \\
\text { assignment. }\end{array}$ & $\begin{array}{l}\text { Assignments and } \\
\text { activities that are } \\
\text { relevant to the real } \\
\text { world. }\end{array}$ & - Floods at your place. & $\begin{array}{l}\text { Writing an appeal } \\
\text { letter to seek } \\
\text { assistance. }\end{array}$ \\
\hline 3 & $\begin{array}{l}\text { Expert } \\
\text { achievement. }\end{array}$ & $\begin{array}{l}\text { Refer to the } \\
\text { expert's view to } \\
\text { help solve a } \\
\text { problem. } \\
\text { Refer to the } \\
\text { multiple } \\
\text { perspectives in } \\
\text { dealing with an } \\
\text { important issue. }\end{array}$ & - Price hikes of goods. & $\begin{array}{l}\text { - A news cutting or } \\
\text { an excerpt of an } \\
\text { interview } \\
\text { involving an } \\
\text { expert with } \\
\text { regard to issues of } \\
\text { price hikes of } \\
\text { good. } \\
\text { - Talk by an expert. } \\
\text { - The historical } \\
\text { account of a } \\
\text { personality or an } \\
\text { expert. }\end{array}$ \\
\hline 4 & $\begin{array}{l}\text { Multiple } \\
\text { perspectives } \\
\text { and } \\
\text { differential } \\
\text { views }\end{array}$ & $\begin{array}{l}\text { Different perspectives } \\
\text { originate from different } \\
\text { views. As such, use a } \\
\text { number of channels, } \\
\text { such as media, to learn } \\
\text { such diverse } \\
\text { perspectives. }\end{array}$ & $\begin{array}{l}\text { - Is it wise for our } \\
\text { nation to send an } \\
\text { astronaut to the } \\
\text { moon? }\end{array}$ & $\begin{array}{ll}\text { - } & \text { Database. } \\
\text { - } & \text { Digital library. } \\
\text { - } & \text { Influential } \\
& \text { websites. }\end{array}$ \\
\hline 5 & Collaboration & $\begin{array}{l}\text { Activities that help the } \\
\text { public, such as those } \\
\text { carried out by a charity } \\
\text { organization. }\end{array}$ & - Homeless people. & $\begin{array}{l}\text { Writing an article } \\
\text { or publishing a } \\
\text { bulletin to } \\
\text { highlight such an } \\
\text { issue to the } \\
\text { general public. }\end{array}$ \\
\hline
\end{tabular}


INTERNATIONAL JOURNAL OF ACADEMIC RESEARCH IN BUSINESS AND SOCIAL SCIENCES Vol. 9, No. 1, Jan, 2019, E-ISSN: 2222-6990 @ 2019 HRMARS

\begin{tabular}{|c|c|c|c|c|}
\hline 6 & Reflection & $\begin{array}{l}\text { Opportunity for } \\
\text { students to think, } \\
\text { reflect, and discuss } \\
\text { their choices. }\end{array}$ & $\begin{array}{l}\text { - Opportunity to make } \\
\text { choices. } \\
\text { - Two-way discussion } \\
\text { process. } \\
\text { - Opportunity to } \\
\text { reflect on online } \\
\text { journals, books, and } \\
\text { materials that have } \\
\text { been read or listen } \\
\text { to. }\end{array}$ & $\begin{array}{l}\text { - Reading articles in } \\
\text { a journal or a blog } \\
\text { and making } \\
\text { reflections. }\end{array}$ \\
\hline 7 & Articulation & $\begin{array}{l}\text { Opportunity for } \\
\text { students to write and } \\
\text { speak out about their } \\
\text { understanding of a } \\
\text { subject matter or an } \\
\text { issue. }\end{array}$ & $\begin{array}{l}\text { - General presentation } \\
\text { in which students } \\
\text { defend their ideas } \\
\text { - Comment on an } \\
\text { issue through online } \\
\text { media, such as } \\
\text { Twitter and } \\
\text { Facebook. }\end{array}$ & $\begin{array}{l}\text { Responding by } \\
\text { posting } \\
\text { comments to } \\
\text { YouTube and } \\
\text { other alternative } \\
\text { media }\end{array}$ \\
\hline 8 & $\begin{array}{l}\text { Training and } \\
\text { Scaffolding }\end{array}$ & $\begin{array}{l}\text { - Knowledge transfer } \\
\text { is not the only } \\
\text { concern. } \\
\text { - Teachers will focus } \\
\text { not only on } \\
\text { teaching but also } \\
\text { on helping students } \\
\text { in constructing } \\
\text { knowledge and } \\
\text { correcting } \\
\text { mistakes. }\end{array}$ & $\begin{array}{l}\text { - Students are given } \\
\text { the opportunity to } \\
\text { write an essay about } \\
\text { themselves. } \\
\text { - The teacher helps } \\
\text { the students to } \\
\text { improve their } \\
\text { writing. } \\
\text { - The teacher supports } \\
\text { the students by } \\
\text { giving online articles, } \\
\text { printed materials, } \\
\text { and others, to them, } \\
\text { with which they will } \\
\text { use as guidelines to } \\
\text { help correct their } \\
\text { mistakes. }\end{array}$ & $\begin{array}{l}\text { - } \quad \text { Essay } \\
\text { composition. }\end{array}$ \\
\hline 9 & $\begin{array}{l}\text { Authentic } \\
\text { assessment }\end{array}$ & $\begin{array}{l}\text { Assessments have to } \\
\text { be aligned with the } \\
\text { students' assignments. }\end{array}$ & $\begin{array}{l}\text { - Assessments must } \\
\text { relate with the } \\
\text { assessments given to } \\
\text { the students. }\end{array}$ & $\begin{array}{l}\text { - } \text { Reports. } \\
\text { - Journals }\end{array}$ \\
\hline
\end{tabular}

Accordingly, the researchers propose the teaching and learning activities based on the nine elements, which will be used to examine the extent to which such leaning authentic will be able to 
INTERNATIONAL JOURNAL OF ACADEMIC RESEARCH IN BUSINESS AND SOCIAL SCIENCES

Vol. 9, No. 1, Jan, 2019, E-ISSN: 2222-6990 (C) 2019 HRMARS

improve students' essay writing ability. Table 3 summarizes the proposed activities that will be used for the following research.

Table 3. The proposed teaching and learning activities for essay writing based on the authentic approach

\begin{tabular}{|c|c|c|c|c|}
\hline Title: & \multicolumn{4}{|c|}{ The effects of bullying } \\
\hline Language skill: & \multicolumn{4}{|c|}{ Essay writing skill } \\
\hline Material: & \multicolumn{4}{|c|}{$\begin{array}{l}\text { 1. Newspaper cuttings (printed or online Berita Harian Online and Utusan } \\
\text { Online, dated 7th. September } 2016 \\
\text { 2. Video clip from You Tube. }\end{array}$} \\
\hline \multicolumn{5}{|l|}{ Teaching step } \\
\hline \multirow[t]{2}{*}{ Set induction } & $\begin{array}{l}\text { Learning } \\
\text { content }\end{array}$ & $\begin{array}{l}\text { Authentic } \\
\text { element }\end{array}$ & Activity & Note \\
\hline & $\begin{array}{l}\text { The bullying } \\
\text { phenomenon } \\
\text { among } \\
\text { adolescents. }\end{array}$ & $\begin{array}{l}\text { The authentic } \\
\text { context. }\end{array}$ & $\begin{array}{l}\text { Students read online } \\
\text { news or watch a video } \\
\text { regarding bullying to } \\
\text { establish the context of } \\
\text { learning. }\end{array}$ & $\begin{array}{l}\text { Learning } \\
\text { material: } \\
\text { Newspaper } \\
\text { cutting or a } \\
\text { video clip on } \\
\text { bullying. }\end{array}$ \\
\hline Step 1 & $\begin{array}{l}\text { The causes of } \\
\text { bullying } \\
\text { among } \\
\text { students. }\end{array}$ & $\begin{array}{l}\text { The views of } \\
\text { experts and } \\
\text { leading } \\
\text { personalities. }\end{array}$ & $\begin{array}{l}\text { Discuss the views of } \\
\text { experts and leading } \\
\text { personalities regarding } \\
\text { the causes and } \\
\text { contributing factors of } \\
\text { bullying in schools and } \\
\text { among adolescents. }\end{array}$ & $\begin{array}{r}\text { Newspaper } \\
\text { cutting or an } \\
\text { excerpt of an } \\
\text { interview with } \\
\text { experts } \\
\text { regarding such } \\
\text { a } \\
\text { phenomenon. }\end{array}$ \\
\hline Step 2 & $\begin{array}{l}\text { The means of } \\
\text { overcoming } \\
\text { bullying. }\end{array}$ & $\begin{array}{l}\text { The } \\
\text { articulation of } \\
\text { views from } \\
\text { multiple, } \\
\text { different } \\
\text { perspectives. }\end{array}$ & 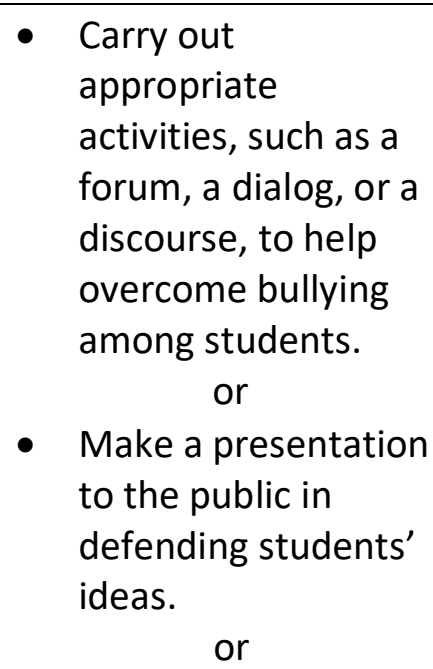 & $\begin{array}{ll}\text { - } & \text { Slides. } \\
\text { - } & \text { Large-size } \\
\text { papers. } & \text { or } \\
\text { - } & \text { Social } \\
\text { media. }\end{array}$ \\
\hline
\end{tabular}


INTERNATIONAL JOURNAL OF ACADEMIC RESEARCH IN BUSINESS AND SOCIAL SCIENCES Vol. 9, No. 1, Jan, 2019, E-ISSN: 2222-6990 @ 2019 HRMARS

\begin{tabular}{|c|c|c|c|c|}
\hline & & & $\begin{array}{l}\text { - Comment on the } \\
\text { issue using online } \\
\text { media, such as } \\
\text { Twitter or Facebook. }\end{array}$ & \\
\hline Step 3 & $\begin{array}{l}\text { Essay writing } \\
\text { on the ways of } \\
\text { overcoming } \\
\text { bullying } \\
\text { among } \\
\text { students or } \\
\text { adolescents. }\end{array}$ & $\begin{array}{l}\text { The training } \\
\text { and } \\
\text { scaffolding }\end{array}$ & $\begin{array}{l}\text { - Students are given } \\
\text { the opportunity to } \\
\text { write their own } \\
\text { essays. } \\
\text { The teacher helps } \\
\text { the students in } \\
\text { correcting their } \\
\text { essays. } \\
\text { The teacher provides } \\
\text { support materials, such } \\
\text { as online articles and } \\
\text { printed materials, which } \\
\text { serve as guidelines to } \\
\text { help them correct their } \\
\text { mistakes on their own. }\end{array}$ & $\begin{array}{l}\text { Support } \\
\text { materials } \\
\text { for the } \\
\text { essay } \\
\text { writing. }\end{array}$ \\
\hline Closure & $\begin{array}{l}\text { Learning } \\
\text { assessment }\end{array}$ & $\begin{array}{r}\text { The authentic } \\
\text { assessment }\end{array}$ & $\begin{array}{l}\text { Re-evaluating student } \\
\text { learning by carrying out } \\
\text { the following activities: } \\
\text { - Reflection. } \\
\text { - Question-and- } \\
\text { Answer. } \\
\text { - Expression of } \\
\text { feelings. } \\
\text { (choose any activities } \\
\text { deemed appropriate) }\end{array}$ & \\
\hline
\end{tabular}

\section{Conclusion}

As discussed above, it is clear that the process of teaching essay writing in the classroom has to take into account several important factors. For example, the learning process needs to be implemented in the actual context that is most appropriate with students' learning needs. Such contextualized learning can be realized with the use of relevant assignments that reflect the real world. In particular, the assignments should be based on inquiry-based, explorative learning activities, through which students can achieve a meaningful learning experience. In addition, students must be given the freedom to express their perceptions and views of the given tasks from various perspectives and roles. Given such freedom, surely the students will be able to learn more efficaciously of the subject matter as well as play an active role in the community. 
INTERNATIONAL JOURNAL OF ACADEMIC RESEARCH IN BUSINESS AND SOCIAL SCIENCES

Vol. 9, No. 1, Jan, 2019, E-ISSN: 2222-6990 (C) 2019 HRMARS

\section{Acknowledgment}

This paper is based on the research project entitled Keberkesanan Pendekatan Pengajaran Bahasa Melayu Secara Autentik dalam Meningkatkan Penulisan Karangan Murid Tingkatan Dua. The authors would like to extend their gratitude to the Research Management and Innovation Centre (RMIC), Sultan Idris Education University, Perak, Malaysia for the University Research Grant (Code 2015-0124106-01) that helped fund the research.

\section{Corresponding Author}

Zulkifli Osman, Malaysia, Email: zulkifli@fbk.upsi.edu.my

\section{References}

Brown, H. D. (2001). Teaching by principles: An interactive approach to language pedagogy. (2nd ed.). New York: Longman.

Donovan, M. S., Bransford, J. D., \& Pellegrino, J. W. (Eds.). (1999). How people learn: Bridging research and practice. Washington, DC: National Academy Press.

Hamid, Z. (2005). Penilaian pengajaran dan pembelajaran Bahasa Melayu. Kuala Lumpur: Dewan Bahasa dan Pustaka.

Herrington, A. J. \& Herrington, J. A. (2007). What is an authentic learning environment?. In L. A. Tomei (Eds.), Online and distance learning: Concepts, methodologies, tools, and applications (pp. 6877). Hershey, PA: Information Science Reference.

Husnin, H., Din, R., Karim, A., Norman, H., \& Hamdan, A. (2013). Assesing authentic learning via storyboarding: A Malaysia Perspective. Asian Social Science, 9(16), 46-53.

Lombardi, M. M. (2007). Authentic Learning for the 21st Century: An Overview. Educause learning initiative. ELI paper 1.

Muijs, D. \& Reynolds, D. (2011). Effective teaching: Evidence and practice. $3^{\text {rd. }}$ ed. Los Angeles. SAGE Publications Ltd.

Newmann, F., Secada, W., \& Wehlage, G. (1995). A guide to authentic instruction and assessment: Vision, standards and scoring. Alexandria, VA: ASCD.

Osman, Z. (2013a). Pembangunan modul pengajaran Bahasa Melayu secara bersepadu. Tesis doktor falsafah yang tidak diterbitkan. Fakulti Pendidikan, Universiti Malaya.

Osman, Z. (2013b). Kebolehlaksanaan dan Kebolehgunaan Modul Pengajaran Bahasa Berlandaskan Pendekatan Holistik. Jurnal Pendeta, Jld. 4, 202-230.

Richards, J. C. (2001). Curriculum development in language teaching. Cambridge: Cambridge Universiti Press.

Tan, M. M. Y. (2012). Kesan penggunaan aktiviti "hands-on" dalam proses pembelajaran sains tahun empat. Kertas kerja yang dibentang dalam Seminar Penyelidikan Tindakan IPG KBL pada 27 \& 28 September 2012.

Yusoff, R., Wah, E. S. S, Jaafar, J., \& Ling, T. T. (2010). Kaedah Suapan dalam Kelas Bahasa Melayu: Satu Tinjauan Awal terhadap Pandangan Guru. In Ambigapathy Pandian, Murshidi Harun @ Zakaria, Tan Hock Thye, Siti Noraini Jupri, and Noraini Ali (Eds.), Pancadimensi pengajaran and pembelajaran bahasa: Trend and amalan. Pulau Pinang: Penerbit Universiti Sains Malaysia (pp. 207-216). 
INTERNATIONAL JOURNAL OF ACADEMIC RESEARCH IN BUSINESS AND SOCIAL SCIENCES

Vol. 9, No. 1, Jan, 2019, E-ISSN: 2222-6990 @ 2019 HRMARS

Zemelman, S., Daniels, H., \& Hyde, A. (2005). Best practices: Today's standards for teaching \& learning in America's School. $3^{\text {rd }}$ Edition. Portsmouth: Heinemann.

Zoghi, M., Zardak, F. M., \& Kazemi, S. A. (2014). The effects of authentic materials on vocabulary development. International Journal of Language Learning and Applied Linguistics World (IJLLALW), 5 (4). 155-160. 